\title{
ANALISIS PEMANFAATAN SEWA BARANG MILIK DAERAH (BMD) TERHADAP PENINGKATAN PENDAPATAN ASLI DAERAH (PAD) KABUPATEN SUMBAWA BARAT TAHUN 2017-2019
}

\author{
Ahdi Topan Sofyan, Ryan Hidayat dan Eko Suryaningsih \\ Universitas Cordova Nusa Tenggara Barat, Indonesia \\ Email: ahditopan15@gmail.com, xiao.yan200991@gmail.com dan \\ suryaningsih.samawi@gmail.com
}

\section{Abstract}

The purpose of this study is (1) to know the tourism tourism of Regional Property Tourism (BMD) where the increase in Regional Native Income (PAD) West Sumbawa Regency in 2017-2019; (2) For the level of effectiveness of the business fund of Regional Property Business (BMD) to the revenue of The Original Region (PAD) west Sumbawa Regency year 2017-2019; (3) For the level of efficiency level of regional property owned enterprises (BMD) around the revenue of The Original Region (PAD) Sumbawa Regency year 2017-2019; (4) To know from the regional property business fund (BMD) to the Regional Revenue Revenue (PAD) West Sumbawa Regency year 2017-2019. This type of research uses quantitative research. Data collection techniques which is how to draw and good name. Life and samples in this study are the Original Regional Income Report (PAD) year 2017-2019. Data analysis of techniques in which analysis of comments, analysis of efficiency ratios, analysis of efficiency ratios and analysis of trends by means of energy squares. The results of the research: (1) There is a share of regional property (BMD) to the Regional Original Income (PAD) in 2017 of 0.42\%; In 2018 by $1.12 \%$; and 2019 at $0.79 \%$. The central level level of regional property rental (BMD) to Regional Original Income (PAD) is 96.15\% in 2017; In 2018 it was 100.51\%; and In 2019 60.54\% was categorized as less. The market for the use of Regional Property Technology (BMD) to Regional Native Income (PAD) is categorized as believing, in 2017 amounted to 19.32\%; In 2018 it was 16.61\% and 2019 was $18.00 \%$. (4) $0.59 \%$ of 2017 trend results; In 2018 it was $0.78 \%$; In 2019 amounted to $0.96 \%$, and the results of the t-test can be concluded that there is a rental income of Regional Property (BMD) to the Regional Native Income (PAD) in West Sumbawa Regency in 2017-2019. Inventory of this thesis research also immobilizes the Local Government so that the inventory of goods belonging to the region both land, equipment and machinery and machinery and buildings on which the goods card is not used for waste form in order to get revenues native districts in West Sumbawa.

Keywords: non-regional waste (BMD); original income area (PAD)

\begin{tabular}{ll}
\hline How to cite: & Sofyan, Ahdi Topan., et.al (2021) Analisis Pemanfaatan Sewa Barang Milik Daerah (BMD) terhadap \\
& Peningkatan Pendapatan Asli Daerah (PAD) Kabupaten Sumbawa Barat Tahun 2017-2019, Syntax Idea \\
& 3(4). http://dx.doi.org/10.36418/syntax-idea.1168 \\
E-ISSN: & 2684-883X \\
Published by: & Ridwan Institute
\end{tabular}




\section{Abstrak}

Tujuan penelitian ini adalah (1) untuk mengetahui kontribusi pemanfaatan sewa Barang Milik Daerah (BMD) terhadap peningkatan Pendapatan Asli Daerah (PAD) Kabupaten Sumbawa Barat 2017-2019; (2) untuk mengetahui tingkat efektifitas dari kontribusi pemanfaatan sewa Barang Milik Daerah (BMD) terhadap peningkatan Pendapatan Asli Daerah (PAD) Kabupaten Sumbawa Barat tahun 2017-2019; (3) untuk mengetahui tingkat efisiensi dari kontribusi Pemanfaatan sewa Barang Milik Daerah (BMD) terhadap peningkatan Pendapatan Asli Daerah (PAD) Kabupaten Sumbawa Barat tahun 2017-2019; (4) untuk mengetahui perkembangan dari kontribusi pemanfaatan sewa Barang Milik Daerah (BMD) terhadap peningkatan Pendapatan Asli Daerah (PAD) Kabupaten Sumbawa Barat tahun 2017-2019. Jenis penelitian menggunakan metode penelitian kuantitatif. Teknik pengumpulan data yang digunakan adalah wawancara dan dokumentasi. Populasi dan sampel dalam penelitian ini adalah laporan realisasi Pendapatan Asli Daerah (PAD) tahun 2017-2019. Teknik analisis data yang digunakan adalah analisis kontribusi, analisis rasio efektifitas, analisis rasio efisiensi dan analisis trend dengan metode kuadrat terkecil. Hasil penelitian menunjukkan: terdapat kontribusi pemanfaatan sewa Barang Milik Daerah (BMD) terhadap Pendapatan Asli Daerah (PAD) pada tahun 2017 sebesar 0,42\%; tahun 2018 sebesar 1,12\%; dan tahun 2019 sebesar 0,79\%. Tingkat efektifitas pemanfaatan sewa Barang Milik Daerah (BMD) terhadap Pendapatan Asli Daerah (PAD) yaitu tahun 2017 sebesar 96,15\%; tahun 2018 sebesar 100,51\%; dan tahun 2019 sebesar 60,54\% dikategorikan kurang efektif. Efektifitas pemanfaatan sewa Barang Milik Daerah (BMD) terhadap Pendapatan Asli Daerah (PAD) dikategorikan efisien, pada tahun 2017 sebesar 19,32\%; tahun 2018 adalah 16,61\% dan tahun 2019 sebesar 18,00\%. Berdasarkan hasil perhitungan trend tahun 2017 sebesar 0,59\%; tahun 2018 sebesar 0,78\%; tahun 2019 sebesar 0,96\%, dan hasil uji-t maka dapat disimpulkan bahwa ada perkembangan kontribusi sewa Barang Milik Daerah (BMD) terhadap Pendapatan Asli Daerah (PAD) di Kabupaten Sumbawa Barat tahun 2017-2019. Penelitian ini juga menyarankan kepada pemerintah daerah agar melakukan inventarisasi terkait barang milik daerah baik berupa tanah, peralatan dan mesin maupun gedung dan bangunan yang tercatat pada kartu inventaris barang yang tidak dipergunakan untuk dimanfaatkan dalam bentuk sewa agar dapat menambah pendapatan asli daerah di Kabupaten Sumbawa Barat.

Kata Kunci: pemanfaatan sewa barang milik daerah (BMD); pendapatan asli daerah (PAD)

\section{Pendahuluan}

Perubahan Undang-Undang nomor 2 tahun 1999 menjadi Undang- Undang nomor 2 tahun 2004 memberikan konsekuensi bertambahnya kewenangan pemerintah daerah sebagai bentuk pelimpahan tugas dari pemerintah pusat. Di samping itu UndangUndang nomor 25 tahun 1999 direvisi menjadi Undang-Undang nomor 34 tahun 2004, yang merupakan aturan perimbangan keuangan antara pemerintah pusat dan daerah. Dampak dari desentralisasi tersebut adalah pemerintah daerah mempunyai kekuasaan yang lebih luas dalam hal pengelolaan aset daerah. Perubahan tersebut meliputi kenaikan jumlah maupun kekayaan negara yang dikuasai pemerintah daerah yang sebelumnya dikuasai oleh pemerintah pusat. 
Kewenangan yang lebih luas memberikan peluang bagi daerah untuk meningkatkan kinerja keuangan dan mengoptimalkan potensi lokalnya, sehingga pada gilirannya kemampuan keuangan daerah menjadi lebih baik, daerah menjadi lebih mandiri, dan ketergantungan kepada pemerintah pusat menjadi semakin kecil (Tamboto, Morasa, \& Mawikere, 2014). Kemandirian ini dapat dicapai dengan mengoptimalkan Pendapatan Asli Daerah (PAD) yang bersumber dari pajak daerah, retribusi hasil pengelolaan kekayaan daerah yang dipisahkan dan lain-lain PAD yang sah, seperti di atur dalam undang-undang 34 tahun 2004 pasal 6 (Atmaja, 2012). Kewenangan yang diberikan berkaitan pula dengan bagaimana pemerintah daerah mampu memaksimalkan kekayaan daerah yang dimiliki misalnya melalui pengelolaan manajemen aset (Jusmin, 2013).

Aset daerah merupakan aspek fundamental yang memiliki peran dan fungsi strategis bagi pemerintahan sehingga perlu dikelola dengan tertib, efektif dan efisien agar dapat didayagunakan secara optimal dalam mendukung peyelenggaraan pemerintahan, pembangunan, pelayanan kepada masyarakat, dan peningkatan PAD (Nurdyansyah \& Andiek, 2017). Aset atau barang milik daerah adalah semua kekayaan daerah baik yang dibeli atau diperoleh atas beban Anggaran Pendapatan dan Belanja Daerah (APBD) maupun yang berasal dari perolehan lain yang sah baik bergerak maupun tidak bergerak beserta bagian-bagiannya ataupun yang merupakan satuan tertentu yang dapat dinilai, dihitung, diukur, atau ditimbang termasuk hewan dan tumbuh-tumbuhan kecuali uang dan surat-surat berharga lainnya (Soleh \& Rochmansjah, 2010).

Berdasarkan (Peraturan Pemerintah nomor 27 pasal 2, 2014) tentang pengelolaan Barang Milik Daerah pasal 2 disebutkan bahwa Barang Milik Daerah meliputi barang yang dibeli atau diperoleh atas beban anggaran pendapatan dan belanja negara atau daerah dan barang yang berasal dari perolehan lainnya yang sah. Barang yang sebagaimana dimaksud adalah barang yang diperoleh dari hibah dan sumbangan atau yang sejenis, barang yang diperoleh sebagai pelaksanaan dari perjanjian atau kontrak, barang yang diperoleh sesuai dengan ketentuan peraturan perundang-undangan atau barang yang diperoleh berdasarkan putusan pengadilan yang telah berkekuatan hukum tetap.

Dalam pasal 1 ayat (28) (Peraturan Menteri Dalam Negeri Republik Indonesia Nomor 19 Tahun 2016, 2016) menyebutkan bahwa Pengelolaan Barang Milik Daerah adalah keseluruhan kegiatan yang meliputi perencanaan kebutuhan dan penganggaran, pengadaan, penggunaan, pemanfaatan, pengamanan dan pemeliharaan, penilaian, pemindahtanganan, pemusnahan, penghapusan, penatausahaan dan pembinaan, pengawasan dan pengendalian.

Pengelolaan aset daerah harus ditangani dengan baik agar aset tersebut dapat menjadi modal awal bagi pemerintah daerah untuk melakukan pengembangan kemampuan keuangannya. Aset jika tidak dikelola dengan semestinya, aset tersebut justru menjadi beban biaya karena sebagian dari aset membutuhkan biaya perawatan atau pemeliharaan dan juga turun nilainya atau terdepresiasi seiring waktu (Mulalinda \& 
Tangkuman, 2014) Pentingnya manajemen aset secara tepat dan berdayaguna, dengan didasari prinsip pengelolaan yang efisien dan efektif, diharapkan akan memberi kekuatan terhadap kemampuan pemerintah dalam membiayai pembangunan daerahnya yang tercermin dalam Pendapatan Asli Daerah (PAD) (Aira, 2015).

Dalam menjaga aset daerah yang dimiliki oleh pemerintah daerah maka diperlukan sebuah peraturan dalam hal ini seperti peraturan daerah mengenai pengelolaan aset daerah didaerah tersebut. Di Kabupaten Sumbawa Barat peraturan daerah mengenai pengelolaan aset daerah telah terdapat (Peraturan Daerah Nomor 7 Tahun, 2018). Bahwasanya Pengelolaan Barang Milik daerah meliputi; perencanaan kebutuhan dan penganggaran, pengadaan, penggunaan, pemanfaatan, pengamanan dan pemeliharaan, penilaian, pemindahtanganan, pemusnahan, penghapusan, penatausahaan, pembinaan, pengawasan dan pengendalian.

Kesadaran pentingnya pengelolaan aset bagi pemerintah daerah semakin hari semakin meningkat seiring dengan perbaikan regulasi pengelolaan aset di tingkat pusat dan daerah, tuntutan pelaporan keuangan serta tuntutan otonomi daerah. Otonomi daerah mengharuskan suatu daerah untuk mandiri dalam melakukan pendanaan termasuk mengoptimalkan sumber-sumber Pendapatan Asli Daerah (PAD). Pemanfaatan aset memberikan peluang bagi daerah untuk meningkatkan pendapatan asli daerahnya serta meningkatkan fasilitas publik. Namun faktanya, banyak aset yang dimiliki oleh pemerintah daerah yang belum mampu menghasilkan keuntungan bagi daerah. Melalui mekanisme pemanfaatan aset inilah diharapkan dapat menjadi peluang bagi daerah untuk mengoptimalisasi aset yang dimiliki sehingga mampu meningkatkan pendapatan asli daerahnya (Runiawati, 2017).

Berdasarkan (Permendagri nomor 17, 2007) pemanfaatan barang milik daerah yang optimal akan membuka lapangan kerja, meningkatkan pendapatan masyarakat dan menambah pendapatan daerah. Pemanfaatan barang milik daerah dilaksanakan oleh pengelola barang dengan persetujuan Gubernur/Bupati/Walikota, untuk barang milik daerah yang berada dalam penguasaan pengelola barang, dan pengguna barang dengan persetujuan pengelola barang, untuk barang milik daerah berupa sebagian tanah dan/atau bangunan yang masih digunakan oleh pengguna barang, dan selain tanah dan/atau bangunan. Pemanfaatan barang milik daerah dilaksanakan berdasarkan pertimbangan teknis dengan memperhatikan kepentingan daerah dan kepentingan umum sepanjang tidak mengganggu pelaksanaan tugas dan fungsi penyelenggaraan pemerintahan daerah. Pemanfaatan barang milik daerah dilakukan tanpa memerlukan persetujuan DPRD (Wibisono, 2019).

Berdasarkan (Peraturan dareah nomor 7 tahun 2018 dalam pasal 1 ayat 28, 2018) dijelaskan bahwa pemanfaatan adalah pendayagunaan barang milik daerah yang tidak dipergunakan sesuai dengan tugas pokok dan fungsi SKPD/unit kerja, dalam bentuk sewa, pinjam pakai, kerjasama pemanfaatan, bangun guna serah dan bangun serah guna dengan tidak mengubah status kepemilikan.

Dari data yang sudah ada diketahui bahwa realisasi penerimaan pemanfaatan aset sewa BMD mengalami peningkatan antara tahun 2017 sampai tahun 2018 dan 
mengalami penurunan pada tahun 2019. Adapun data penerimaan pemanfaatan aset sewa barang milik daerah selama tiga tahun terakhir bisa dilihat pada tabel berikut :

Tabel 1

Penerimaan Pemanfaatan Aset sewa Tanah

\begin{tabular}{cc}
\hline Tahun Anggaran & Realisasi Sewa BMD \\
\hline 2017 & Rp. 224.306.850 \\
\hline 2018 & Rp. 364.080 .094 \\
\hline 2019 & Rp. 182.458 .815 \\
\hline Sumber $:$ Data diolh Bidang Aset BPAD Kabuten Sumbarat
\end{tabular}

Sumber : Data diolah Bidang Aset BPAD Kabupaten Sumbawa Barat

Berdasarkan tabel 1, terlihat bahwa realisasi penerimaan pemanfaatan aset sewa tanah milik Pemerintah Kabupaten Sumbawa Barat pada tahun 2017 senilai Rp. 224.306.850 dan pada tahun 2018 mengalami peningkatan penerimaan mencapai Rp. 364.080.094. Sedangkan di tahun 2019 mengalami penurunan dari dua tahun sebelumnya dengan jumlah realisasi senilai Rp. 182.458.815 hal ini disebabkan karena masih adanya tunggakan pembayaran sewa tanah oleh penyewa yang harus disetorkan ke kas daerah.

Pendapatan sewa barang milik daerah Kabupaten Sumbawa Barat merupakan hal menarik untuk dikaji, karena memberikan nuansa baru sebagai salah satu upaya untuk mewujudkan otonomi daerah yang luas, nyata dan bertanggung jawab. Sewa barang milik daerah merupakan salah satu pendapatan asli daerah yang sangat potensial, dimana barang milik daerah merupakan aset tetap pemerintah yang disewakan sebagai tempat usaha yang dikenakan biaya sesuai tarif yang telah ditentukan. Adapun penulis tertarikuntuk melakukan penelitian terhadap pemanfaatan sewa barang milik daerah Kabupaten Sumbawa Barat karena hasil pemanfaatan sewa barang milik daerah dari tahun 2017 sampai tahun 2018 mengalami peningkatan dan mengalami penurunan di tahun 2019, aset daerah/barang milik daerah merupakan kekayaan daerah yang perlu dikelola secara optimal, membuka lapangan pekerjaan, dan menambah pendapatan masyarakat dan penulis ingin memberikan informasi tentang pemanfaatan sewa barang milik daerah untuk meningkatkan Pendapatan Asli Daerah (PAD).

Salah satu tolak ukur kemampuan daerah dalam mengeksploitasi pendapatan tersebut adalah seberapa besar sektor pemanfaatan aset sewa barang milik daerah tersebut memberikan kontribusi terhadap penerimaan daerah, khususnya pendapatan asli daerah yang nantinya dapat dipergunakan sebagai sumber dana dan biaya untuk mencukupi kebutuhan belanja daerah yang bersangkutan. Dengan kata lain pendapatan asli daerah merupakan sumber pembiayaan bagi pemerintah daerah, oleh sebab itu daerah diwajibkan untuk menggali segala sumber-sumber keuangannya sendiri berdasarkan peraturan perundang-undangan yang berlaku. Kebaharuan dalam penelitian ini adalah lokasi penelitian Badan Pendapatan Aset Daerah Kabupaten Sumbawa Barat. Sedangkan manfaat penelitian ini sebagai acuan bagi pemerintah kabupaten sumbaawa barat dalam memberikan sumbangan pemikiran dalam meningkatkan pedapatan asli daerah. 


\section{Metode Penelitian}

Penelitian ini menggunakan jenis metode penelitian kuantitatif, yaitu penelitian dengan memperoleh data yang berupa angka yang mengacu pada data, pemanfaatan teori yang ada sebagai bahan pendukung, serta menghasilkan suatu teori.

Pendekatan metode ini diangkat dari data lalu yang diproses menjadi informasi yang berharga bagi pengambilan keputusan (Idrus, 2009). Definisi lain menyebutkan penelitian kuantitatif adalah penelitian yang banyak menuntut penggunaan angka, mulai dari pengumpulan data, penafsiran terhadap data tersebut, serta penampilan dari hasilnya, demikian pula pada tahap kesimpulan penelitian akan lebih baik bila disertai tabel, grafik atau tampilan lainnya.

Menurut (Sugiyono, 2014), Metode kuantitatif adalah metode yang sudah cukup lama digunakan sebagai metode untuk penelitian. Disebut metode kuantitatif karena data penelitian berupa angka-angka dan analisis menggunakan statistik. Adapun sampel penelitian ini laporan realisasi pemanfaatan sewa barang milik daerah dan laporan realisasi pendapatan asli daerah.

\section{Hasil dan Pembahasan}

\section{A. Hasil Penelitian}

\section{Analisis Data}

Seperti yang telah dibahas dalam metode penelitian, analisis yang digunakan dalam penelitian ini adalah analisis kontribusi, analisis rasio efektifitas, analisis rasio efisiensi dan analisis trend.

a. Kontribusi Pemanfaatan sewa Barang Milik Daerah terhadap Pendapatan Asli Daerah.

Pemanfaatan sewa barang milik daerah adalah salah satu komponen retribusi daerah yang memberikan sumbangan yang cukup berarti pada pendapatan asli daerah. Pemanfaatan sewa barang milik daerah terdiri dari sewa alat berat dan lab, sewa tanah dan sewa mesin pertanian.

Untuk mengetahui seberapa besar peranan sewa barang milik daerah terhadap PAD, menggunakan rasio antara jumlah sewa barang milik daerah dengan PAD dikalikan 100\%. Semakin besar nilai persentase kontribusi sewa barang milik daerah terhadap pendapatan asli daerah semakin dinilai baik.

Kontribusi sewa barang milik daerah terhadap pendapatan asli daerah di Kabupaten Sumbawa Barat dihitung dengan menggunakan rumus sebagai berikut:

\section{Pn= QXn x 100\%}

\section{QYn}

Keterangan :

Pn : Kontribusi sumber-sumber PAD terhadap PAD

QX: Jumlah penerimaan sewa barang milik daerah

QY: Jumlah penerimaan Pendapatan Asli Daerah

$\mathrm{N}$ : Tahun atau periode tertentu 
Perhitungan kontribusi sewa barang milik daerah terhadap pendapatan asli daerah Kabupaten Sumbawa Barat adalah sebagai berikut:

Tahun $2017=\frac{625.001 .850}{148.888 .446 .165} \times 100 \%=0,42 \%$

Tahun $2018=\frac{653.295 .094}{58.448 .937 .184} \times 100 \%=1,12 \%$

Tahun $2019=\frac{575.173 .815}{72.869 .945 .142,29} \times 100 \%=0,79 \%$

Tabel 2

Kontribusi sewa BMD terhadap PAD Kabupaten Sumbawa

Barat Tahun 2017-2019

\begin{tabular}{ccl}
\hline $\begin{array}{c}\text { Tahun } \\
\text { Anggaran }\end{array}$ & $\begin{array}{c}\text { Kontribusi } \\
(\%)\end{array}$ & Kriteria \\
\hline 2017 & $0,42 \%$ & Sangat Kurang \\
\hline 2018 & $1.12 \%$ & Sangat Kurang \\
\hline 2019 & $0,79 \%$ & Sangat Kurang \\
\hline
\end{tabular}

Sumber : Data diolah BPAD Kabupaten Sumbawa Barat(2020)

Dari hasil perhitungan tabel 2 diatas, dapat dilihat bahwa kontribusi sewa Barang Milik Daerah (BMD) terhadap Pendapatan Asli Daerah (PAD) Kabupaten Sumbawa Barat mengalami fluktuasi yang bervariasi antara $0,42 \%$ sampai dengan 1,12\%. Kontribusi terendah terjadi pada tahun 2017 sebesar 0,42\%, disebabkan karena kanaikan pendapatan asli daerah. Kontribusi terbesar pada tahun 2018 sebesar 1.12\%. Sedangkan kontribusi pada tahun 2019 mengalami penurunan yaitu sebesar $0.79 \%$.

Berdasarkan tabel 2, menunjukkan bahwa kontribusi pemanfaatan sewa Barang Milik Daerah (BMD) terhadap Pendapatan Asli Daerah (PAD) Kabupaten Sumbawa Barat sangat kurang. Hal ini disebabkan karena masih terdapat barang milik daerah yang belum dikelola secara optimal dan belum dimanfaatkan untuk mengoptimalkan Pendapatan Asli Daerah (PAD) Pemerintah Kabupaten Sumbawa Barat.

b. Analisis Rasio Efektifitas Pemanfaatan sewa Barang Milik Daerah

Tingkat efektifitas pemanfaatan sewa Barang Milik Daerah (BMD) Kabupaten Sumbawa Barat dihitung dengan membandingkan antara realisasi penerimaan sewa Barang Milik Daerah (BMD) dengan target sewa Barang Milik Daerah (BMD) yang sebelumnya telah ditetapkan. Apabila hasil perhitungan efektifitas sewa barang milik daerah mendekati $100 \%$ maka kinerja dalam 
penyewaan Barang Milik Daerah (BMD) di Kabupaten Sumbawa Barat semakin baik. Target sewa Barang Milik Daerah (BMD) Kabupaten Sumbawa Barat tahun 2017 sampai tahun 2019 dapat dilihat dalam tabel 3.

Tabel 3

Target Pemanfaatan sewa Barang Milik Daerah (BMD) Tahun 2017-2019

\begin{tabular}{|c|c|c|c|c|}
\hline \multirow[b]{2}{*}{ No } & \multirow[b]{2}{*}{ Sektor Sewa BMD } & \multicolumn{3}{|c|}{ Tahun } \\
\hline & & 2017 & 2018 & 2019 \\
\hline 1. & Sewa Alat Berat dan Lab & 500.000 .000 & 500.000 .000 & 500.000 .000 \\
\hline 2. & Sewa Tanah & 150.000 .000 & 150.000 .000 & 150.000 .000 \\
\hline 3. & Sewa Mesin Pertanian & & & 300.000 .000 \\
\hline & TOTAL & 650.000 .000 & 650.000 .000 & 950.000 .000 \\
\hline
\end{tabular}

Berdasarkan tabel 3 dapat dilihat bahwa target sewa Barang Milik Daerah (BMD) pada tahun 2017 sampai tahun 2018 tidak mengalami perubahan yaitu sebesar Rp.650.000.000. Sedangkan pada tahun 2019 mengalami peningkatan target disebabkan penambahan dari target penyewaan alat pertanian. Jumlah target pada tahun 2019 yaitu sebesar Rp.950.000.000.-

Rasio efektifitas pemanfaatan sewa barang milik daerah dapat diketahui dengan rumus sebagai berikut :

\section{Rasio Efektifitas Sewa BMD = Realisasi Sewa BMD $\times 100 \%$ Target Sewa BMD}

Sedangkan perhitungan nilai efektifitas sewa barang milik daerah adalah :

$$
\begin{gathered}
\text { Tahun 2017 }=\frac{625.001 .850}{650.000 .000} \times 100 \%=96,15 \% \\
\text { Tahun } 2018=\frac{653.295 .094}{650.000 .000} \times 100 \%=100,51 \%
\end{gathered}
$$

$$
575.173 .815
$$

Tahun $2019=\frac{}{950.000 .000} \times 100 \%=60,54 \%$ 
Tabel 4

Efektifitas Pemanfaatan Sewa Barang Milik Daerah (BMD) Kabupaten Sumbawa Barat Tahun 2017-2019

\begin{tabular}{ccl}
\hline $\begin{array}{c}\text { Tahun } \\
\text { Anggaran }\end{array}$ & $\begin{array}{c}\text { Efektifitas } \\
(\mathbf{\%})\end{array}$ & Kriteria \\
\hline 2017 & $96,15 \%$ & Cukup Efektif \\
\hline 2018 & $100,51 \%$ & Sangat Efektif \\
\hline 2019 & $60,54 \%$ & Kurang Efektif \\
\hline Sumber : Data diolah BPAD Kabupaten Sumbawa Barat, (2020)
\end{tabular}

Dari perhitungan tabel 4, dapat dilihat bahwa tingkat efektifitas sewa Barang Milik Daerah (BMD) di Kabupaten Sumbawa Barat pada tahun 2017 sampai tahun 2018 mengalami kenaikan yaitu antara 96,15\% sampai 100,51\%. Sedangkan pada tahun 2019 justru mengalami penurunan yang drastis dengan tingkat efektifitas sebesar $60,54 \%$ dan merupakan tingkat efektifitas yang terendah selama tiga tahun terakhir. Tingkat efektifitas yang tertinggi adalah tahun 2018 sebesar 100,51\% yang berarti efektifitas sewa Barang Milik Daerah (BMD) mencapai target dalam realisasinya.

c. Analisis Rasio Efisiensi Pemanfaatan sewa Barang Milik Daerah

Efisiensi pemanfaatan sewa Barang Milik Daerah (BMD) dapat dihitung dengan cara membandingkan antara biaya pengumutan sewa Barang Milik Daerah (BMD) dengan realisasi sewa Barang Milik Daerah (BMD). Apabila perhitungan semakin kecil maka semakin efisien. Dengan semakin efisien sewa Barang Milik Daerah (BMD), maka kinerja dalam memperoleh realisasi sewa Barang Milik Daerah (BMD) di Kabupaten Sumbawa Barat semakin baik. Terkait besar biaya pemungutan $r$ ealisasi sewa Barang Milik Daerah (BMD) diambil dari belanja barang dan jasa dari tahun 2017 sampai tahun 2019, dapat dilihat pada tabel dibawah ini.

\section{Tabel 5}

Biaya Pemanfaatan sewa Barang Milik Daerah (BMD) Kabupaten Sumbawa Barat Tahun 2017-2019

\begin{tabular}{|c|c|c|c|c|}
\hline \multirow[b]{2}{*}{ No } & \multirow{2}{*}{$\begin{array}{c}\text { Belanja Barang dan } \\
\text { Jasa }\end{array}$} & \multicolumn{3}{|c|}{ Tahun } \\
\hline & & 2017 & 2018 & 2019 \\
\hline 1. & $\begin{array}{l}\text { Suku Cadang Alat } \\
\text { Berat }\end{array}$ & 94.800 .000 & 85.000 .000 & \\
\hline 2. & Jasa Kalibrasi Alat Lab & 19.200 .000 & & 69.700 .000 \\
\hline 3. & Oil dan Grease & 6.750 .000 & 23.655 .000 & 33.840 .800 \\
\hline & TOTAL & 120.750 .000 & 108.655 .000 & 103.540 .800 \\
\hline
\end{tabular}

Dari hasil perhitungan diatas, dapat dilihat bahwa kontribusi sewa Barang Milik Daerah (BMD) terhadap Pendapatan Asli Daerah (PAD) Kabupaten 
Sumbawa Barat mengalami fluktuasi yang bervariasi antara $0,42 \%$ sampai dengan 1,12\%. Kontribusi terendah terjadi pada tahun 2017 sebesar 0,42\%, disebabkan karena kanaikan Pendapatan Asli Daerah. Kontribusi terbesar pada tahun 2018 sebesar $1.12 \%$. Sedangkan kontribusi pada tahun 2019 mengalami penurunan yaitu sebesar $0.79 \%$.

Berdasarkan tabel 4 menunjukkan bahwa kontribusi pemanfaatan sewa Barang Milik Daerah (BMD) terhadap Pendapatan Asli Daerah (PAD) Kabupaten Sumbawa Barat sangat kurang. Hal ini disebabkan karena masih terdapat barang milik daerah yang belum dikelola secara optimal dan belum dimanfaatkan untuk mengoptimalkan Pendapatan Asli Daerah (PAD) Pemerintah Kabupaten Sumbawa Barat.

d. Analisis Rasio Efektifitas Pemanfaatan sewa Barang Milik Daerah

Tingkat efektifitas pemanfaatan sewa Barang Milik Daerah (BMD) Kabupaten Sumbawa Barat dihitung dengan membandingkan antara realisasi penerimaan sewa Barang Milik Daerah (BMD) dengan target sewa Barang Milik Daerah (BMD) yang sebelumnya telah ditetapkan. Apabila hasil perhitungan efektifitas sewa barang milik daerah mendekati $100 \%$ maka kinerja dalam penyewaan Barang Milik Daerah (BMD) di Kabupaten Sumbawa Barat semakin baik. Target sewa Barang Milik Daerah (BMD) Kabupaten Sumbawa Barat tahun 2017 sampai tahun 2019 dapat dilihat dalam tabel berikut.

Tabel 6

Target Pemanfaatan Sewa Barang Milik Daerah (BMD) Tahun 2017-2019

\begin{tabular}{lcccc}
\hline & & \multicolumn{3}{c}{ Tahun } \\
\cline { 3 - 5 } No & Sektor Sewa BMD & $\mathbf{2 0 1 7}$ & $\mathbf{2 0 1 8}$ & $\mathbf{2 0 1 9}$ \\
\hline 1. & Sewa Alat Berat dan Lab & 500.000 .000 & 500.000 .000 & 500.000 .000 \\
\hline 2. & Sewa Tanah & 150.000 .000 & 150.000 .000 & 150.000 .000 \\
\hline 3. & Sewa Mesin Pertanian & & & 300.000 .000 \\
\hline & TOTAL & 650.000 .000 & 650.000 .000 & 950.000 .000 \\
\hline
\end{tabular}

Sumber : BPAD Kab. Sumbawa Barat (2020)

Berdasarkan tabel 6 dapat dilihat bahwa target sewa Barang Milik Daerah (BMD) pada tahun 2017 sampai tahun 2018 tidak mengalami perubahan yaitu sebesar Rp.650.000.000. Sedangkan pada tahun 2019 mengalami peningkatan target disebabkan penambahan dari target penyewaan alat pertanian. Jumlah target pada tahun 2019 yaitu sebesar Rp.950.000.000.-

Rasio efektifitas Pemanfaatan sewa barang milik daerah dapat diketahui dengan rumus sebagai berikut :

\section{Rasio Efektifitas Sewa BMD = Realisasi Sewa BMD $\times 100 \%$ Target Sewa BMD}


Sedangkan perhitungan nilai efektifitas sewa barang milik daerah adalah :

\begin{tabular}{|c|c|c|}
\hline \multicolumn{3}{|c|}{625.001 .850} \\
\hline \multicolumn{3}{|c|}{ Tahun $2017=\frac{}{650.000 .000} \times 100 \%=96,15 \%$} \\
\hline \multicolumn{3}{|c|}{653.295 .094} \\
\hline \multicolumn{3}{|c|}{ Tahun $2018=\frac{}{650.000 .000} \times 100 \%=100,51 \%$} \\
\hline \multicolumn{3}{|c|}{575.173 .815} \\
\hline \multicolumn{3}{|c|}{ Tahun $2019=\frac{}{950.000 .000} \times 100 \%=60,54 \%$} \\
\hline \multicolumn{3}{|c|}{$\begin{array}{c}\text { Tabel } 7 \\
\text { Efektifitas Pemanfaatan sewa } \\
\text { Barang Milik Daerah (BMD) Kabupaten } \\
\text { Sumbawa Barat Tahun 2017-2019 }\end{array}$} \\
\hline $\begin{array}{c}\text { Tahun } \\
\text { Anggaran }\end{array}$ & $\begin{array}{c}\begin{array}{c}\text { Efektifitas } \\
(\%)\end{array} \\
\end{array}$ & Kriteria \\
\hline 2017 & $96,15 \%$ & Cukup Efektif \\
\hline 2018 & $100,51 \%$ & Sangat Efektif \\
\hline 2019 & $60,54 \%$ & Kurang Efektif \\
\hline
\end{tabular}

Sumber : Data diolah BPAD Kabupaten Sumbawa Barat, (2020)

Dari perhitungan tersebut, dapat dilihat bahwa tingkat efektifitas sewa Barang Milik Daerah (BMD) di Kabupaten Sumbawa Barat pada tahun 2017 sampai tahun 2018 mengalami kenaikan yaitu antara 96,15\% sampai 100,51\%. Sedangkan pada tahun 2019 justru mengalami penurunan yang drastis dengan tingkat efektifitas sebesar $60,54 \%$ dan merupakan tingkat efektifitas yang terendah selama tiga tahun terakhir. Tingkat efektifitas yang tertinggi adalah tahun 2018 sebesar 100,51\% yang berarti efektifitas sewa Barang Milik Daerah (BMD) mencapai target dalam realisasinya.

e. Analisis Rasio Efisiensi Pemanfaatan sewa Barang Milik Daerah

Efisiensi pemanfaatan sewa Barang Milik Daerah (BMD) dapat dihitung dengan cara membandingkan antara biaya pemungutan sewa Barang Milik Daerah (BMD) dengan realisasi sewa Barang Milik Daerah (BMD). Apabila perhitungan semakin kecil maka semakin efisien. Dengan semakin efisien sewa Barang Milik Daerah (BMD), maka kinerja dalam memperoleh realisasi sewa Barang Milik Daerah (BMD) di Kabupaten Sumbawa Barat semakin baik. Terkait besar biaya pengumutan realisasi sewa Barang Milik Daerah (BMD) diambil dari belanja barang dan jasa dari tahun 2017 sampai tahun 2019, dapat dilihat pada tabel dibawah ini. 
Tabel 8

Biaya Pemanfaatan Sewa Barang Milik Daerah (BMD) Kabupaten Sumbawa Barat Tahun 2017-2019

\begin{tabular}{|c|c|c|c|c|}
\hline \multirow[b]{2}{*}{ No } & \multirow{2}{*}{$\begin{array}{c}\text { Belanja barang dan } \\
\text { jasa }\end{array}$} & \multicolumn{3}{|c|}{ Tahun } \\
\hline & & 2017 & 2018 & 2019 \\
\hline 1. & $\begin{array}{l}\text { Suku Cadang Alat } \\
\text { Berat }\end{array}$ & 94.800 .000 & 85.000 .000 & \\
\hline 2. & Jasa Kalibrasi Alat Lab & 19.200 .000 & & 69.700 .000 \\
\hline 3. & Oil dan Grease & 6.750 .000 & 23.655 .000 & 33.840 .800 \\
\hline & TOTAL & 120.750 .000 & 108.655 .000 & 103.540 .800 \\
\hline
\end{tabular}

Sumber : BPAD Kabupaten Sumbawa Barat (2020)

Berdasarkan tabel 8 diketahui biaya yang dikeluarkan dalam pengumutan sewa Barang Milik Daerah (BMD) pada tahun 2017 sebesar Rp.120.750.000. pada tahun 2018 mengalami penurunan biaya sebesar Rp.108.655.000 dan pada tahun 2019 biaya yang dikeluarkan turun sebesar Rp. 103.540.800.-

Efisiensi Pemanfaatan sewa Barang Milik Daerah (BMD) dapat diketahui dengan rumus sebagai berikut :

\section{Rasio Efisiensi Sewa BMD = Biaya sewa BMD $\times 100 \%$ Realisasi sewa BMD}

Perhitungan nilai efisiensi adalah :

$$
\begin{aligned}
& \text { Tahun } 2017=\frac{120.750 .000}{625.001 .850} \times 100 \%=19,32 \% \\
& \text { Tahun } 2018=\frac{108.655 .000}{653.295 .094} \times 100 \%=16,63 \% \\
& \text { Tahun } 2019=\frac{103.540 .800}{575.173 .815} \times 100 \%=18,00 \%
\end{aligned}
$$

Tabel 9

Efisiensi Pemanfaatan Sewa

Barang Milik Daerah

Kabupaten Sumbawa Barat

Tahun 2017-2019

\begin{tabular}{ccc}
\hline $\begin{array}{c}\text { Tahun } \\
\text { Anggaran }\end{array}$ & $\begin{array}{c}\text { Efisiensi } \\
(\mathbf{\%})\end{array}$ & \multicolumn{1}{l}{ Kriteria } \\
\hline 2017 & $19,32 \%$ & Efisien \\
\hline 2018 & $16,63 \%$ & Efisien \\
\hline 2019 & $18,00 \%$ & Efisien \\
\hline Sumber : Data diolah BPAD Kabupaten Sumbawa Barat (2020)
\end{tabular}


Dari perhitungan tabel 9 diatas, dapat dilihat bahwa tingkat efisiensi sewa Barang Milik Daerah (BMD) di Kabupaten Sumbawa Barat pada tahun 2017 tingkat efisiensi sebesar 19,32\% yang merupakan tingkat efisiensi terendah. Selanjutnya tahun 2018 tingkat persentasenya lebih kecil yaitu sebesar 16,63\%, sedangkan pada tahun 2019 tingkat persentasenya lebih besar yaitu 18\%. Semakin kecil tingkat efisiensi maka semakin bagus kinerja dalam pengumutannya. Sehingga dapat disimpulkan tingkat efisien paling rendah yaitu pada tahun 2017 dan tingkat efisien yang paling tinggi yaitu tahun 2018.

\section{B. Pembahasan}

1. Analisis Kontribusi Pemanfaatan sewa BMD terhadap PAD

Hasil tabel 5 menunjukkan bahwa kontribusi pemanfaatan sewa Barang Milik Daerah (BMD) terhadap Pendapatan Asli Daerah (PAD) di Kabupaten Sumbawa Barat sangat kurang. Ini dapat dilihat dari tahun 2017 bahwa persentase kontribusi sewa Barang Milik Daerah (BMD) di Kabupaten Sumbawa Barat hanya sebesar 0,42\%. Pada tahun 2018 kontribusi sewa Barang Milik Daerah (BMD) mengalami kenaikan meskipun kenaikannya tidak terlalu besar yaitu $0,7 \%$ dengan jumlah persentase pada tahun 2018 yaitu $1.12 \%$ tetapi kontribusinya masih dikategorikan sangat kurang. Kemudian pada tahun 2019 persentase kontribusi mengalami penurunan dari tahun 2018 sebesar 0,33\%. Kontribusi sewa Barang Milik Daerah (BMD) pada tahun 2019 masih sangat kurang yaitu sebesar $0,79 \%$. Sehingga kontribusi sewa baarang milik daerah tidak dapat dijadikan tolak ukur dalam penerimaan.

Pendapatan asli daerah di Kabupaten Sumbawa Barat dikarenakan kontribusinya dari tahun 2017 sampai tahun 2019 masih sangat kurang. Hal ini disebabkan masih terdapat Barang Milik Daerah (BMD) yang belum bisa dimanfaatkan untuk peningkatan Pendapatan Asli Daerah (PAD) di Kabupaten Sumbawa Barat.

Berdasarkan tabel 5 diatas, maka hasil pengujian Hipotesis H1 diterima, yaitu terdapat kontribusi pemanfaatan sewa Barang Milik Daerah (BMD) terhadap peningkatan Pendapatan Asli Daerah (PAD) Kabupaten Sumbawa Barat tahun 2017-2019.

a. Analisis Efektifitas Pemanfaatan sewa barang milik daerah

Hasil perhitungan efektifitas menunjukkan bahwa realisasi penerimaan sewa Barang Milik Daerah (BMD) pada tahun 2017 sebesar Rp.625.001.850 sedangkan untuk targetnya sebesar Rp.650.000.000. Sehingga jika dibuat sesuai perhitungan di atas maka akan memperoleh hasil realisasi sebesar 96,15\%, jadi pada 2017 tingkat efektifitas sewa Barang Milik Daerah (BMD) dikategorikan cukup efektif. Sedangkan tahun 2018 mengalami kenaikan realisasi sebesar Rp.653.295.094. Sedangkan untuk target tetap sama dari tahun sebelumnya yaitu Rp. 650.000.000 dengan tingkat efektifitasnya 100,51\% yang dikategorikan bahwa pada tahun 2018 penerimaan sewa Barang Milik Daerah (BMD) sangat 
efektif. Hal ini disebabkan oleh meningkatnya jumlah realisasi sewa tanah milik pemerintah Kabupaten Sumbawa Barat.

Pada tahun 2019 tingkat efektifitas sewa Barang Milik Daerah (BMD) kurang efektif, hal ini disebabkan karena jumlah realisasi mengalami penurunan dari tahun-tahun sebelumnya yaitu sebesar Rp. 575.173.815 sedangkan anggaran yang ditargetkan meningkat sebesar Rp. 950.000.000. Sehingga tingkat efektifitasnya sebesar 60,54\%. Dari hasil analisis di atas diketahui bahwa sewa Barang Milik Daerah (BMD) pada tahun 2017 sampai tahun 2018 dikategorikan efektif karena ditiap tahunnya jumlah realisasi melampui target yang ditetapkan. Akan tetapi dalam realisasinya belum cukup berkontribusi untuk peningkatan Pendapatan Asli Daerah (PAD) di Kabupaten Sumbawa Barat.

Berdasarkan tabel 7 maka pengujian hipotesis $\mathrm{H} 2$ ditolak, karena tingkat efektifitas dari kontribusi pemanfaatan sewa Barang Milik Daerah (BMD) terhadap peningkatan Pendapatan Asli Daerah (PAD) Kabupaten Sumbawa Barat tahun 2017-2019, tidak sangat efektif.

b. Analisis Efisiensi pemanfaatan sewa barang milik daerah

Hasil tabel 6 menunjukkan bahwa pada tahun 2017 realisasi penerimaan sewa Barang Milik Daerah (BMD) sebesar Rp. 625.001.850 dengan biaya yang diperlukan untuk mendapatkan realisasi tersebut sebesar Rp. 120.750.000, sehingga jika dibuat sesuai perhitungan analisis efisiensi maka akan memperoleh hasil sebesar 19,32\% dengan kategori efisien. Pada tahun 2018 realisasi sebesar Rp.653.295.094 dengan biaya sebesar Rp.108.655.000 dengan tingkat efisiensi meningkat sebesar 16,61\%. Pada tahun 2019 jumlah realisasi sebesar Rp. 575.173.815 dan biaya yang dibutuhkan sebesar Rp.103.540.800, sedangkan tingkat efesiennya mengalami penurunan sebesar 18,00\% yang disebabkan oleh realisasinya lebih kecil dibandingkan dengan dua tahun sebelumnya. Dari hasil analisis diatas diketahui bahwa sewa Barang Milik Daerah (BMD) pada tahun 2017 sampai tahun 2019 dikategorikan efisien dalam pengumutannya, Akan tetapi belum cukup berkontribusi untuk peningkatan Pendapatan Asli Daerah (PAD) di Kabupaten Sumbawa Barat.

Berdasarkan tabel 9 maka pengujian hipotesis H3 ditolak, karena tingkat efisiensi dari Kontribusi Pemanfaatan sewa Barang Milik Daerah (BMD) terhadap peningkatan Pendapatan Asli Daerah (PAD) Kabupaten Sumbawa Barat tahun 2017-2019, tidak sangat efisien.

c. Analisis Perkembangan kontribusi sewa BMD terhadap PAD

Berdasarkan hasil perhitungan dengan metode LEAS SQUARE dengan menggunakan rumus $\mathrm{Y}^{\prime}=\mathrm{a}+\mathrm{bx}$, maka ditemukan persamaan trendnya yaitu $\mathrm{Y}^{\prime}$ $=0,777 \%+0,185(\mathrm{x})$. Pada tahun 2017 nilai trend sebesar $0.59 \%$ dan di tahun 2018 mengalami kenaikan dengan nilai trend sebesar $0,78 \%$ dan mengalami kenaikan hingga mencapai 0,96\% pada tahun 2019.

Untuk menjawab hipotesis terkait ada dan tidak adanya perkembangan kontribusi sewa Barang Milik Daerah (BMD) terhadap Pendapatan Asli Daerah (PAD) perlu dilakukan uji-t dan menetukan taraf siginfikan sebesar 5\% sehingga 
ditemukan nilai t tabel sebesar 4,303. Sedangkan nilai perhitungan uji-t sebesar 0.623. Melalui uji t dan penentuan taraf signifikan sebesar 5\% dapat ditarik kesimpulan bahwa ada perkembangan kontribusi sewa Barang Milik Daerah (BMD) terhadap Pendapatan Asli Daerah (PAD) di Kabupaten Sumbawa Barat karena nilai uji-t sebesar 0,623 terletak di antara nilai taraf signikan yaitu 4,303 dan -4,303. Dengan kata lain nilai uji t terletak di daerah penerimaan.

Berdasarkan pengujian hipotesis di atas maka $\mathrm{H} 4$ diterima karena terdapat perkembangan kontribusi pemanfaatan sewa Barang Milik Daerah (BMD) terhadap peningkatan Pendapatan Asli Daerah (PAD) Kabupaten Sumbawa Barat tahun 2017-2019.

\section{Kesimpulan}

Berdasarkan uraian diatas dan hasil analisis data yang penulis peroleh dalam penelitian ini, maka dapat diambil kesimpulan Kontribusi Pemanfaatan sewa barang milik daerah terhadap Pendapatan Asli Daerah Kabupaten Sumbawa Barat tahun 2017 sampai tahun 2019 masih sangat kurang. Kontribusi sewa barang milik daerah di Kabupaten Sumbawa Barat mengalami fluktuasi, Pada tahun 2017 hanya sebesar 0,42\% mengalami kenaikan pada tahun 2018 yaitu sebesar 1.12\% dan pada tahun 2019 kontribusi mengalami penurunan yaitu sebesar 0,79\%. Berdasarkan tabel 4.5 maka H1 diterima yaitu terdapat kontribusi pemanfaatan sewa Barang Milik Daerah (BMD) terhadap Pendapatan Asli Daerah (PAD) Kabupaten Sumbawa Barat tahun 2017-2019, efektifitas pemanfaatan sewa barang milik daerah di Kabupaten Sumbawa Barat pada tahun 2017 sampai tahun 2018 mengalami kenaikan yaitu antara 96,15\% sampai $100,51 \%$ yang dikategorikan cukup efektif dalam penerimaannya. Sedangkan pada tahun 2019 merupakan tingkat efektifitas yang terendah, karena mengalami penurunan dengan tingkat efektifitas sebesar 60,54\% yang dikategorikan kurang efektif. Berdasarkan tabel 4.7 maka pengujian hipotesis $\mathrm{H} 2$ ditolak, karena tingkat efektifitas dari Kontribusi Pemanfaatan sewa Barang Milik Daerah (BMD) terhadap peningkatan Pendapatan Asli Daerah (PAD) Kabupaten Sumbawa Barat tahun 2017-2019, tidak sangat efektif, efisiensi penerimaan sewa barang milik daerah di Kabupaten Sumbawa Barat pada tahun 2017 sebesar 19,32\%. Pada Tahun 2018 tingkat efisiensi meningkat sebesar 16,61\%. Pada tahun 2019 tingkat efesiennya mengalami penurunan sebesar $18,00 \%$. Berdasarakan perhitungan efisiensi, pemanfaatan sewa barang milik daerah di Kabupaten Sumbawa Barat dapat digolongkan efisien dalam penerimaannya. Karena semakin kecil tingkat efisiensi, maka semakin efisien kinerja dalam pengumutannya. Berdasarkan tabel 4.9 maka pengujian hipotesis H3 ditolak, karena tingkat efisiensi dari Kontribusi Pemanfaatan sewa Barang Milik Daerah (BMD) terhadap peningkatan Pendapatan Asli Daerah (PAD) Kabupaten Sumbawa Barat tahun 2017-2019, tidak sangat efisien, dari persamaan trend $\mathrm{Y}^{\prime}=0,777 \%+0,185(\mathrm{x})$, ditemukan bahwa nilai trend kontribusi pemanfaatan sewa barang milik daerah terhadap Pendapatan Asli Daerah pada tahun 2017 nilai trendnya sebesar $0.59 \%$ dan di tahun 2018 nilaitrend sebesar 0,78\% dan pada tahun 2019 sebesar 0,96\%. Hasil pengujian Hipotesis dengan 
Ahdi Topan Sofyan, Ryan Hidayat dan Eko Suryaningsih

uji-t diketahui bahwa thitung 0,623 terletak diantara 4,303 ttabel sehingga Ha diterima berarti ada perkembangan kontribusi pemanfaatan sewa barang milik daerah terhadap Pendapatan Asli Daerah di Kabupaten Sumbawa Barat yang signifikan pada tahun 2017 sampai 2018. Berdasarkan pengujian hipotesis diatas maka $\mathrm{H} 4$ diterima karena terdapat perkembangan Kontribusi Pemanfaatan sewa Barang Milik Daerah (BMD) terhadap peningkatan Pendapatan Asli Daerah (PAD) Kabupaten Sumbawa Barat tahun 20172019. 


\section{BIBLIOGRAFI}

Aira, Aras. (2015). Peran manajemen aset dalam pembangunan daerah. Kutubkhanah, 17(1), 21-39. Google Scholar

Atmaja, Khoirul Fariz. (2012). Analisis Rasio Keuangan Untuk Memprediksi Kemungkinan Financial Distress. Accounting Analysis Journal, 1(2). Google Scholar

Idrus, Muhammad. (2009). Metode penelitian ilmu sosial. Yogyakarta: Erlangga. Google Scholar

Jusmin. (2013). Pengaruh Manjemen Aset Terhadap Tingkat Optimalisasi Aset Tetap Pemerintah Kota Baubau. Tesis. Yogyakarta: Fakultas Ekonomika Dan Bisnis, Universitas Gajah Mada. Google Scholar

Mulalinda, Veronika, \& Tangkuman, Steven J. (2014). Efektivitas penerapan sistem dan prosedur akuntansi aset tetap pada dinas pendapatan, pengelolaan keuangan dan aset daerah kabupaten sitaro. Jurnal EMBA: Jurnal Riset Ekonomi, Manajemen, Bisnis Dan Akuntansi, 2(1). Google Scholar

Nurdyansyah, Nurdyansyah, \& Andiek, Widodo. (2017). Manajemen Sekolah Berbasis ICT. Universitas Muhammadiyah Sidoarjo. Google Scholar

Peraturan Daerah Nomor 7 Tahun. (2018). Pengelolaan Barang Milik Daerah.

Peraturan dareah nomor 7 tahun 2018 dalam pasal 1 ayat 28. (2018).

Peraturan Menteri Dalam Negeri Republik Indonesia Nomor 19 Tahun 2016. (2016). Pedoman Pengelolaan Barang Milik Daerah. Peraturan Menteri Dalam Negeri Republik Indonesia Nomor 19 Tahun 2016. Google Scholar

Peraturan Pemerintah (PP) nomor 27 pasal 2. (2014). Pengelolaan Barang Milik Daerah pasal 2.

Permendagri nomor 17. (2007). Pemanfaatan barang milik daerah.

Runiawati, Nunung. (2017). Pemanfaatan Barang Milik Daerah (Suatu pendekatan teoritis dan praktis dalam menentukan metode pemanfaatan aset). Jurnal Manajemen Pelayanan Publik, 1(1), 45-58. Google Scholar

Soleh, Chobib, \& Rochmansjah, Heru. (2010). Pengelolaan keuangan dan aset daerah: sebuah pendekatan struktural menuju tata kelola pemerintahan yang baik. Fokusmedia.

Sugiyono. (2014). Metode Penelitian Pendidikan Pendekatan Kuantitatif, Kualitatif 
Ahdi Topan Sofyan, Ryan Hidayat dan Eko Suryaningsih

Dan $R \& D$. Bandung: Alfabeta.

Tamboto, Laedy, Morasa, Jenny, \& Mawikere, Lidia. (2014). Analisis kemampuan keuangan daerah dalam masa otonomi daerah pada Kabupaten Minahasa Tenggara. Jurnal EMBA: Jurnal Riset Ekonomi, Manajemen, Bisnis Dan Akuntansi, 2(2). Google Scholar

Wibisono, Gatot Irfan. (2019). Harmonisasi Hukum Dalam Perjanjian Sewa Menyewa Barang Milik Daerah Kota Bekasi. Jurnal Reformasi Hukum, 23(2). Google Scholar

Copyright holder :

Ahdi Topan Sofyan, Ryan Hidayat dan Eko Suryaningsih (2021)

First publication right :

Journal Syntax Idea

This article is licensed under:

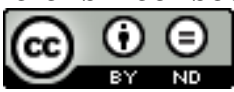

